\title{
Exploring Learning Styles in a Portuguese Engineering School: Are They Different in Different Courses?
}

\author{
https://doi.org/10.3991/ijep.v10i6.15237 \\ Marina Sousa ${ }^{(凶)}$, Eunice Fontão \\ Institute of Engineering of Porto, Polytechnic of Porto, Portugal \\ maseisep.ipp.pt
}

\begin{abstract}
The Kolb model is widely used to analyze the learning style of engineering students; however, there are no published studies carried out in Portugal. This study was applied to students who had just began their courses at a Portuguese engineering school. This study object is to assess whether there is a clearly majority learning style; whether there are differences in the learning style among all students and between students in the industrial management course and those in the technological engineering courses. The results allow the pedagogical practice improvement in the classroom regarding the effectiveness increase of the teaching process. This study results also allow improving the way students approach the study, overcoming difficulties in understanding the topics studied, improving the construction of their skills and increasing the quality of the learning process.
\end{abstract}

Keywords - Engineering education; experiential learning; Kolb learning styles inventory; learning; learning styles; vocational predictor

\section{$1 \quad$ Introduction}

It is a common state that engineering schools do not prepare well enough their students for the present-day job market. Today's professional face a global market and international jobs that have both competition and innovation needs. For this reality professionals are required to have both the traditional scientific and technological skills and also modern skills, like social and management skills, whether those are industrial or organizational. Traditional engineering training does not provide this type of modern skills [1] [2] ${ }^{1}$.

As a result, field employers and professional organizations recommend that students, in addition to learning concepts, or above all, also acquire the necessary skills for their use in a real context [3]. Thus, the aim in current education is, for an effective convergence of academic knowledge with a scientific basis that higher education must provide and the professional experience that requires the integration of this knowledge in the business reality.

\footnotetext{
${ }^{1}$ Note: These Course Accreditation Agencies have an international scope and in practice, induce their requirements in most of the national Accreditation Agencies in a context of a global economy.
} 
The problem generated by this issue reveals the need to establish recommendations for engineering schools to include a management course unit in mechanical, civil and computer graduations. Although cross-cutting skills development is now a common requirement for all academic studies and all its curricular units [4], the truth is that in Engineering Schools the institutional culture is different from Management Schools and that cultural and disciplines differences have repercussions for the development of essential generic skills [5], at least in students perception of its importance.

This distinctiveness requires specific skills for management field professors in engineering schools, particularly in appropriate and effective pedagogical practices for achieving these objectives that, in general, these teachers do not master.

In fact, professor's recruitment in Engineering Schools is traditionally done among engineers or professional scientists, based on their skills for profession exercise or on the academic skills proved during their training. It is assumed that professors have pedagogical skills to teach due to their high academic qualifications but, in fact, they do not have specific skills or knowledge in educational sciences. Professors teach in the same way that they have learned and absorb, through continued practice, the institutional culture methodologies that permeate. They try, in this way, to overcome the epistemological differences between the educational sciences and the didactic practices of engineering [6] [7].

As a result, engineering students are exposed to a multidisciplinary field and to different teachers, each one with their own and pedagogically poorly structured approach. This difference is more emphatic in management disciplines learning, which requires specific concepts of the social sciences, imposing that students leave their vocational comfort zone which lend them choose to an engineering course [8].

Several researchers have been working on this problem [9]. Several authors understand that the use of style learning concept allows the adoption of more effective pedagogical practices, in the classroom and in the field. Cagiltay [10] studied the relationship between students learning styles and their performance in engineering education programs. Bajpai, SinghRaghuwanshi, \& Taskar [11], report that a better knowledge and understanding of learning styles allows professors to configure a multivariate style that effectively reaches the largest number of students. Ictenbas \& Eryilmaz [12] confirm that several teaching modes should be integrated in courses for engineering students with different prior backgrounds. Several other authors refer to similar and positive aspects related to the use of learning styles as an instrument for improving teaching conditions [13] [14] [6].

Other studies report that improvements in the teaching-learning process are obtained when combining teachers teaching mode with students learning style, in what it constitutes a new approach to that process [15] [16].

In this context it was established, as an object of this study, the following questions evaluation: is there a clear majority learning style among students who have chosen an engineering course? Are there significant differences in the learning style among students who have chosen to attend the various specialties of engineering courses? Are there significant differences in learning style between engineering students who have chosen to take an industrial management course and those who have chosen technological engineering courses? 
The following sections include a critical reference to learning style concepts and models, and the selected model (Kolb) is discussed with greater emphasis. The description of the methodology related with the empirical study follows and the main results obtained are described and discussed.

\section{Background Information}

The learning style concept, although is not universally consolidated [17], is widely addressed in the published literature, as can be inferred from Table 1.

Table 1. Learning style concept

\begin{tabular}{|c|c|}
\hline Learning style concept & Reference \\
\hline $\begin{array}{l}\text { "The preferences students have for thinking, relating to others, and particular } \\
\text { types of classroom environments and experiences" }\end{array}$ & [18] quoted by [19, p. 79] \\
\hline $\begin{array}{l}\text { "The cognitive, affective, and physiological traits that are relatively stable in- } \\
\text { dicators of how learners perceive, interact with, and respond to the learning } \\
\text { environment" }\end{array}$ & [20] quoted by [21, p. 87] \\
\hline $\begin{array}{l}\text { "A classifier of students according to where they fit on a number of scales } \\
\text { pertaining to the ways they receive and process information" }\end{array}$ & {$[22$, p. 674] } \\
\hline $\begin{array}{l}\text { "A particular way in which an individual learns; a mode of learning; an indi- } \\
\text { vidual's preferred or best manner(s) in which to think, process information } \\
\text { and demonstrate learning; an individual's preferred means of acquiring } \\
\text { knowledge and skills; habits, strategies, or regular mental behaviours con- } \\
\text { cerning learning, particularly deliberate educational learning, that an individ- } \\
\text { ual display". }\end{array}$ & {$[23, \mathrm{p} .41]$} \\
\hline $\begin{array}{l}\text { "The preferred way that the individual deals with given information and how } \\
\text { she/he constructs meaning out of stimuli" }\end{array}$ & {$[24$, p. XIX] } \\
\hline $\begin{array}{l}\text { "A biologically and developmentally imposed set of personal characteristics } \\
\text { that make the same teaching and learning methods effective for some and in- } \\
\text { effective for others" }\end{array}$ & {$[25$, p. 132] } \\
\hline $\begin{array}{l}\text { "A particular mode according to which an individual learns and thinks, a pre- } \\
\text { ferred means of acquiring knowledge, and habits and strategies associated } \\
\text { with learning" }\end{array}$ & {$[17$, p. 2$]$} \\
\hline
\end{tabular}

According to Zapalska \& Dabb [19, pp. 79-80] "these preferred styles result from one's past life experiences, genetic make-up, life and educational experiences and the demands of the present environment."

Coffield, Moseley, Hall, \& Ecclestone [26], in a seminal work, perform a systematic analysis and a critical review of learning styles models, also address the pedagogy implications and the formulation of teaching and research policies. The authors quote Mitchell [27] to refer to the existence of more than 100 learning styles models, a plethora of unstructured models that can be ordered using the Curry [28] layer model as a construct that can be understood as a classifier of cognitive volatility (Figure 1). 


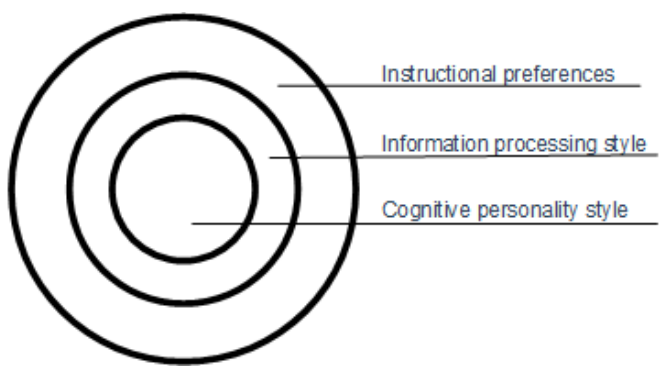

Fig. 1. Curry's model of learning styles [28].

According to this model, each layer represents an aspect of the learning style preference. The innermost layer represents the cognitive personality style, or the individual's approach to assimilating knowledge, and is considered the most stable dimension of learning. The middle layer represents the individual's information processing style and explores the intellectual approach to information assimilation. The outermost layer considers the instructional preference or the learning environment choice. This layer is the most easily influenced and least stable aspect of the learning style preference. A fourth layer called social interaction was later included, describing an individual's preference for social interaction during learning [29].

From this review, 71 models of learning styles were selected and, after a first screening, 13 models were chosen based on the following criteria: their theoretical importance in the field as a whole, the diffusion of its use, commercial or academic, and its influence on other models of learning styles. On these models, internal consistency analysis, test/retest of reliability, construct validity and predictive validity were made. The tests results revealed some weaknesses in all analysis instruments of the learning style evaluated.

One of these models, defined by Kolb [24] [30] [31] based on how people perceive and process information, has been used successfully in engineering education. Like others, such as McKenna, Copnell, Butler, \& Lau [29] studies, presents evidence of noncompliance with some of the criteria specified in the tests - which can be determined by the use of ipsative scales - but the reliability is high, and the behaviour in general has been improved, particularly in version 3 , used in this study, especially when used as a self-assessment tool. However, other authors have confirmed not only the reliability but also the internal validity of the Kolb measurement instrument [32].

This has determined its choice because it has been in use for more than 30 years, and it is suitable for higher education environments [33]. Kolb's experiential learning theory offers an alternative to traditional classroom didactic and behavioural approaches, providing personal change and development as part of a learning cycle [34] [35].

Kolb's Learning Style Inventory, consisting of twelve questions with four options each, forces the respondents to assign priorities, from 1 to 4 , to each option, rather than treating them as four independent factors. This format, called ipsative, determines that the sums obtained for each variable are constant for each individual. Unlike what happens on a normative scale (Likert scale, for example, where an individual's attribute is measured in relation to the score obtained by other individuals on that attribute), an 
ipsative scale measures the attribute weight in an individual's set of attributes. The ipsative scale is commonly used in the areas of personality measurement, vocational choice and assessment of values and attitudes where the scale values are interrelated [36].

There are references in the literature recommending the non-application of standard statistical analysis procedures for normative data [37] [36], namely factor analysis, to sets of ipsative variables [38], because sometimes the results of this analysis show less reliability and confiability.

Some more conservative approaches recommend that ipsative scales not be used. A less conservative approach is to carry out the analysis and to be very careful in the interpretation phase, avoiding the use of these scales in exploratory studies however may use in confirmatory studies, and always cross-validating the data obtained [39]. An alternative approach is to transform ipsative data into compositional data, which can be the object of conventional statistical analysis [40].

Kolb's approach consists of three main components: (i) a theory of experiential learning; (ii) the Learning Styles Inventory (LSI), an instrument to test and apply the model; (iii) a graphic model of the learning cycle.

i. The theory of experiential learning states that learning is most effective when the teaching-learning process includes a cycle of four key characteristics: a concrete experience related to the phenomenon under study (why); which creates the need for a time of reflective observation of the phenomenon in its real context (what?); that leads to the perception of the concepts that integrate the explanation of the phenomenon (how?); and the induction of these concepts in new situations (what if?).

ii. The LSI is a survey consisting of 12 questions, each with four options, which should be rated between 1 and 4, without repeating the score in each question. Kolb defines the four variables of his graphic reference (Concrete Experience - CE, Reflective Observation - RO, Abstract Conceptualization - AC, Active Experimentation - AE) through partial sums of these values, which are then registered in the reference, defining a point in one of the quadrants that qualifies the respondent's learning style.

iii. The graphic framework proposed by Kolb consists of two significant Cartesian axes, to which two dimensions are associated: on the vertical axis, perception (how we perceive things); and on the horizontal axis, processing (how we do things). Perception has two limits, the concrete (the student perceives better seeing or feeling) and the abstract (the student perceives better handling ideas, concepts or symbols). The perception capacity of a thing is located somewhere in the continuous line that joins these two extremes, the vertical axis of the Cartesian plane.

The two processing limits are the active (the student does) and the reflective (the student thinks). Someone's processing capacity is located somewhere on the continuous line that joins these two extremes, the horizontal axis of the Cartesian plane. Based on these two continuous Kolb identifies four learning styles: diverging, assimilating, converging and accommodating, Figure 2. 


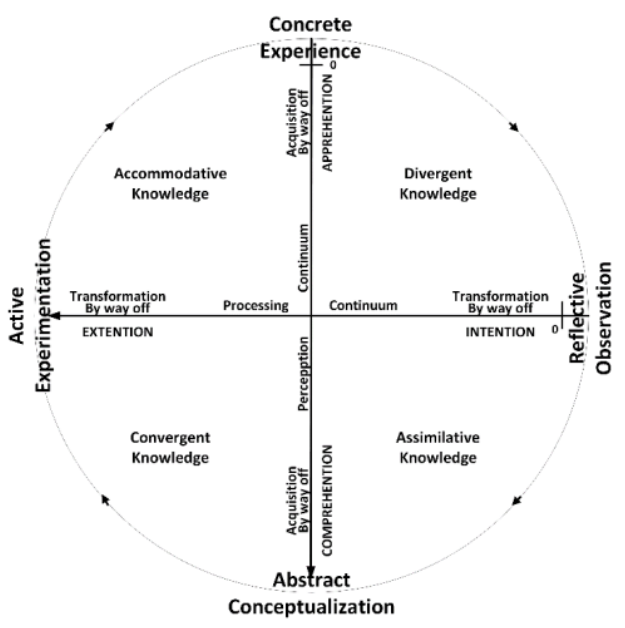

Fig. 2. Graphic reference for the Kolb model, adapted from Kolb [41].

Each of the learning styles corresponds to a definition of the learning characteristics, Table 2 [42].

Table 2. Description of the learning styles characteristics, adapted from [43] [42].

\begin{tabular}{|l|l|}
\hline Convergent & $\begin{array}{l}\text { Strong in practical application of ideas } \\
\text { May focus on hypo-deductive reasoning for specific problems } \\
\text { Emotionless } \\
\text { Has limited interests. }\end{array}$ \\
\hline Divergent & $\begin{array}{l}\text { Strong in imaginative ability } \\
\text { Good at generating ideas and seeing things from different perspectives } \\
\text { Interested in people } \\
\text { Broad cultural interests. }\end{array}$ \\
\hline Assimilative & $\begin{array}{l}\text { Strong capacity to create theoretical models } \\
\text { Strong in inductive reasoning } \\
\text { Concerned with abstract concepts instead of people. }\end{array}$ \\
\hline Accommodative & $\begin{array}{l}\text { Great ability to get things done } \\
\text { Capable to take risks } \\
\text { Performs well when needed to react immediately to circumstances } \\
\text { Intuitively solve problems. }\end{array}$ \\
\hline
\end{tabular}

Felder, Felder, \& Dietz [44], although they have some reservations, they suggest that the learning style may be a vocational predictor. Jones, Reichard, \& Mokhtari [45] are the most assertive in this statement, but their study focuses on various types of disciplines and not on types of courses or scientific domains. Kolb [24] states that the learning style it is not a psychological trait, but a dynamic state that results from a synergistic transition between the person and the environment. Additionally, the author concludes that learning styles are influenced by culture, personality type, educational specialization, career choice, work and present tasks. In this way, they are, in some way, predictors of vocational choices. Table 3 shows the synthesis of these aspects. 
Table 3. Relationship between specialized learning styles and five levels of behaviour [46].

\begin{tabular}{|l|l|l|l|l|}
\hline \multicolumn{1}{|c|}{ Behavior level } & \multicolumn{1}{|c|}{ Diverging } & \multicolumn{1}{c|}{ Assimilating } & \multicolumn{1}{c|}{ Converging } & \multicolumn{1}{c|}{ Accommodating } \\
\hline Personality types & Introverted feeling & Introverted intuition & Extraverted thinking & $\begin{array}{l}\text { Extraverted sensa- } \\
\text { tion }\end{array}$ \\
\hline $\begin{array}{l}\text { Educational speciali- } \\
\text { zation }\end{array}$ & $\begin{array}{l}\text { Arts, English, His- } \\
\text { tory, Psychology }\end{array}$ & $\begin{array}{l}\text { Mathematics, Physi- } \\
\text { cal Science }\end{array}$ & $\begin{array}{l}\text { Engineering, Medi- } \\
\text { cine }\end{array}$ & $\begin{array}{l}\text { Education Commu- } \\
\text { nication Nursing }\end{array}$ \\
\hline Professional career & Social Service Arts & $\begin{array}{l}\text { Sciences Research } \\
\text { Information }\end{array}$ & $\begin{array}{l}\text { Engineering Medi- } \\
\text { cine Technology }\end{array}$ & $\begin{array}{l}\text { Sales Social Service } \\
\text { Education }\end{array}$ \\
\hline Current job & Personal jobs & Information jobs & Technical jobs & Executive jobs \\
\hline $\begin{array}{l}\text { Adaptive competen- } \\
\text { cies }\end{array}$ & Valuing skills & Thinking skills & Decision skills & Action skills \\
\hline
\end{tabular}

Discordant voices are also found in the literature: Felder \& Silverman [22] claim that the incompatibility between student learning styles and teacher teaching styles determines poor performance of the teaching-learning process; Holvikivi [6] states that there is still a long way to find an efficient pedagogical practice to train engineering students; Riener \& Willingham [47, p. 35] claim that "students differ in their abilities, interests, and background knowledge, but not in their learning styles. Students may have preferences about how to learn, but no evidence suggests that catering to those preferences will lead to better learning".

In summary, we can accept - although with some dissenting voices - that the determination of the learning style of each student is an adequate instrument for pedagogical practice configuration of the teaching-learning process [48] and, probably, for assessing student's vocational agreement with the course they attend. Accordingly, a good teaching style should balance the preferences of the students to whom it is addressed [49]. Pedagogical practices that do not take into account the coexisting learning styles in the classroom generate discomfort in students and lack of efficiency and effectiveness in learning outcomes [9].

\section{$3 \quad$ Methodology}

The study was carried out at the Polytechnic School of Engineering in Porto from September to October 2019, using students from the Computer Engineering, Civil Engineering and Industrial Management and Engineering courses.

All students involved in the study were explained the objectives and the questionnaire and their participation were volunteer and consented. Data collection was carried out with the questionnaire in paper format. Table 4 shows the distribution of students among the various engineering courses under study, all enrolled in the first year of the respective course. 
Table 4. Sample

\begin{tabular}{|l|c|}
\hline \multicolumn{1}{|c|}{ Course } & Number of students \\
\hline Civil Engineering & 42 \\
\hline Industrial Management and Engineering & 27 \\
\hline Computer Engineering & 63 \\
\hline Total & 132 \\
\hline
\end{tabular}

As mentioned earlier, the instrument selected for this study was the Kolb Learning Style Inventory Version 3.1 (KLSI 3.1) developed by David A. Kolb and was adapted to Portuguese. KLSI 3.1 is a short questionnaire with 12 items that asks respondents to rank four sentence endings that correspond to the four learning modes: Concrete Experience (CE), Reflective Observation (RO), Abstract Conceptualization (AC), and Active Experimentation (AE).

After data collection and validation, it was released and processed in the Statistical Package for Social Sciences (SPSS) version 26.0 for Windows. Descriptive statistics, means and standard deviation were calculated for the variables $\mathrm{CE}, \mathrm{RO}, \mathrm{AC}, \mathrm{AE}$ and for the combinations of $\mathrm{AC}$ and $\mathrm{CE}$ (AC-CE) and $\mathrm{AE}$ and RO (AE-RO). Cronbach's alpha coefficients values were calculated as a measure of internal consistency, a correlation matrix for scale construct validity, a factor analysis to explore construct validity and t-tests for testing differences.

\section{$4 \quad$ Results}

Table 5 shows the results for a Cronbach alpha coefficients reliability analysis of the internal consistencies of the KLSI scales and an analysis of the scale intercorrelations using Pearson product moment correlations.

The coefficients for $\mathrm{CE}, \mathrm{AC}, \mathrm{RO}$ and EA, ranged between 0.73 and 0.77 . Since all values are greater than 0.7 , these results suggest that the scales have good internal consistency reliability. Additionally, these results are in line with the values obtained in other studies [50].

The results for the correlations between scales matching the hypothesis that there are two bipolar dimensions, $\mathrm{AC}-\mathrm{CE}$ and $\mathrm{AE}-\mathrm{RO}$ are uncorrelated. Also, the $\mathrm{CE}$ and $\mathrm{AC}$ scales are uncorrelated with $\mathrm{AE}-\mathrm{RO}$ and $\mathrm{AE}$ and $\mathrm{RO}$ are uncorrelated with $\mathrm{AC}-\mathrm{CE}$. As predicted in the Kolb model, both $\mathrm{AC}$ and $\mathrm{CE}$ and $\mathrm{AE}$ and $\mathrm{RO}$ are highly negatively correlated. 
Table 5. Coefficient alpha reliability and scale intercorrelations

\begin{tabular}{|l|c|c|c|c|c|c|}
\hline & $\mathbf{C E}$ & $\mathbf{R O}$ & $\mathbf{A C}$ & $\mathbf{A E}$ & $\mathbf{A C}-\mathbf{C E}$ & $\mathbf{A E}-\mathbf{R O}$ \\
\hline $\mathrm{CE}$ & $(0.742)$ & $-.433^{*}$ & $-.400^{*}$ & -0.06 & $-.786^{*}$ & .217 \\
\hline $\mathrm{RO}$ & & $(0.766)$ & -0.16 & $-.484^{*}$ & 0.12 & $-.866^{*}$ \\
\hline $\mathrm{AC}$ & & & $(0.734)$ & $-.339^{*}$ & $.862^{*}$ & -0.08 \\
\hline $\mathrm{AE}$ & & & & $(0.734)$ & -.195 & $.845^{*}$ \\
\hline $\mathrm{AC}-\mathrm{CE}$ & & & & & & -0.17 \\
\hline $\mathrm{AE}-\mathrm{RO}$ & & & & & & \\
\hline
\end{tabular}

Although ipsative data limitations for the study of the internal characteristics of an instrument such as LSI are well known, factor analysis remains the most appropriate method for identifying internal validity of the instrument [32]. Table 6 reports the results of a principal components analysis of the four scales for the sample, used to study the relationships between the scales. Guided for previous research [51] [52] [53] [32] [50], the technique was used to extract three and two factors using the four primary scales. The first solution - three factors - produced 1 factor consisting of an AE/RO bipolar dimension. Factors 2 and 3 are more difficult to analyse, seems to be single factors of CE and AC respectively. The second solution - two factors - led to a factor 1 consisted of an AE/RO bipolar dimension and factor 2 an AC/CE bipolar dimension. All the factors from both solutions produce eigenvalues greater than 1 .

So, the factor analysis of the scales is not completely consistent with the correlations between scales for the three factors solution but is consistent for the two factors solution. This last solution supports the predicted internal structure of the LSI.

Table 6. Factor analyses of the scales.

\begin{tabular}{|l|c|c|c|c|c|}
\hline & \multicolumn{3}{|c|}{ Three Factor Solution } & \multicolumn{2}{c|}{ Two Factor Solution } \\
\hline & Factor 1 & Factor 2 & Factor 3 & Factor 1 & Factor 2 \\
\hline $\mathrm{CE}$ & -0.061 & 0.961 & -0.267 & 0.194 & -0.780 \\
\hline $\mathrm{AC}$ & -0.131 & -0.190 & 0.972 & 0.023 & 0.897 \\
\hline $\mathrm{RO}$ & -0.708 & -0.596 & -0.377 & -0.923 & 0.030 \\
\hline $\mathrm{AE}$ & 0.952 & -0.128 & -0.276 & 0.781 & -0.132 \\
\hline Variance (\%) & 35.686 & 33.257 & 30.869 & 37.500 & 35.788 \\
\hline Cumulative (\%) & 1.43 & 68.942 & 99.811 & & 73.288 \\
\hline Eigen Value & 1.33 & 1.24 & 1.50 & 1.43 \\
\hline \multicolumn{2}{|l}{ Varimax rotation with Kaiser normalization } \\
\hline
\end{tabular}

Figure 3 shows the scores distribution to the KLSI questions for all students in the sample. The questions $7 \mathrm{~d}$ (practice and try out things), $4 \mathrm{~b}$ (by actions), $8 \mathrm{a}$ (see the results of work), $3 \mathrm{a}$ (reason things out) show scores higher than $80 \%$ and the questions 4a (own experiences), 1a (feelings) 3d (energetic and enthusiastic) show scores below $40 \%$. 


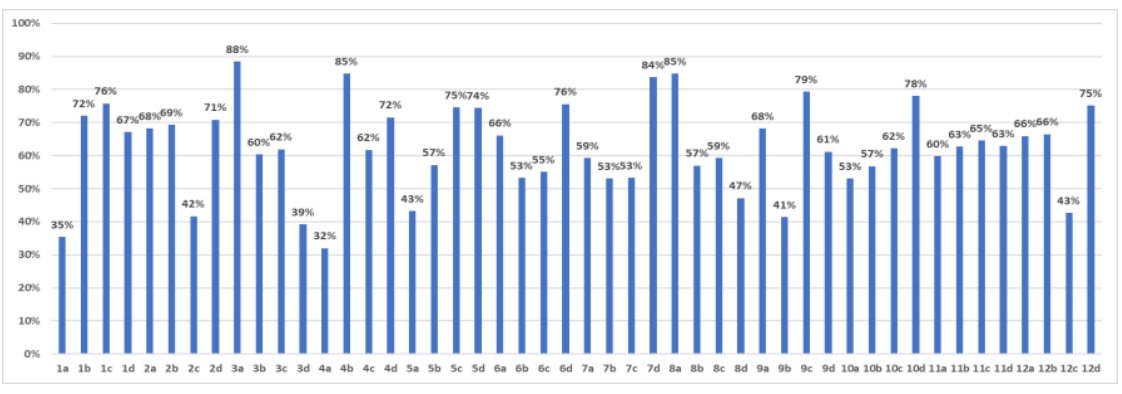

Fig. 3. Scores distribution to the KLSI questions.

Table 7 shows the results of the averages for the sample organized by the three courses under study. The domain with the highest mean score was active experimentation (AE) and the lowest was concrete experience (CE) for all the courses. As can be read from Table 7 , students from the three engineering courses predominately have a preference for abstractness over concreteness (CE-AC) and least preference for action over reflection (AE-RO).

Table 7. Mean scores and standard deviations (SD). CIV- Civil Engineering; IME Industrial Management and Engineering; INF - Informatics Engineering.

\begin{tabular}{|l|c|c|c|c|c|c|c|c|}
\hline & \multicolumn{2}{|c|}{ CIV } & \multicolumn{2}{c|}{ IME } & \multicolumn{2}{c|}{ INF } & \multicolumn{2}{c|}{ Total } \\
\hline \multicolumn{1}{|c|}{ Scale } & Mean & SD & Mean & SD & Mean & SD & Mean & SD \\
\hline CE & 22.88 & 4.68 & 22.07 & 6.69 & 23.17 & 6.38 & 22.86 & 5.932 \\
\hline AC & 33.00 & 5.10 & 33.89 & 6.39 & 33.16 & 6.05 & 33.26 & 5.806 \\
\hline RO & 28.52 & 6.70 & 29.37 & 6.19 & 29.35 & 6.62 & 29.09 & 6.527 \\
\hline AE & 35.60 & 5.26 & 34.30 & 6.77 & 34.29 & 6.14 & 34.70 & 5.998 \\
\hline CE-AC & 10.12 & 7.98 & 11.81 & 11.69 & 9.98 & 10.40 & 10.40 & 9.936 \\
\hline AE-RO & 7.07 & 10.63 & 4.93 & 11.49 & 4.94 & 10.73 & 5.61 & 10.819 \\
\hline
\end{tabular}

The four basic styles - diverging, assimilating, converging and accommodating type are created by dividing the AC-CE and AE-RO scores at the fiftieth percentile of the total norm group. The cut point for the AC-CE scale is +7 , and the cut point for the $\mathrm{AE}-\mathrm{RO}$ scale is +6 . The Accommodating type would be defined by an AC-CE raw score $<=7$ and an AE-RO score $>=7$, the Diverging type by AC-CE $<=7$ and AE-RO $<=6$, the Converging type by $\mathrm{AC}-\mathrm{CE}>=8$ and $\mathrm{AE}-\mathrm{RO}>=7$, and the Assimilating type by $\mathrm{AC}$ $\mathrm{CE}>=8$ and AE-RO <=6. [50, p. 14].

The learning style preferences (in \%) for the sample are shown in Figure 4a) and for the courses in Figure 4b). For the sample assimilating (36\%) learning style is mostly preferred, followed by converging $(31 \%)$ learning style. The assimilating learning style is mostly preferred by Civil Engineering (29\%) and Industrial Management and Engineering $(52 \%)$ students and converging learning style is mostly preferred by Informatics Engineering (37\%) students. 


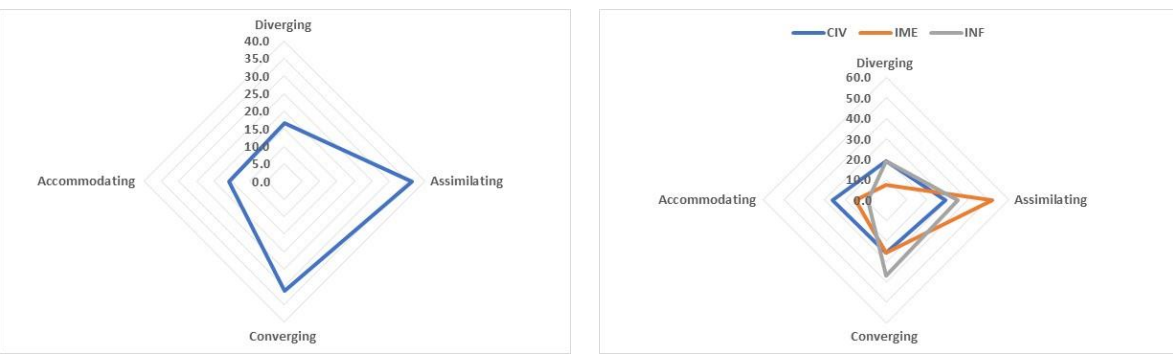

Fig. 4. Learning style preferences. a) sample b) CIV- Civil Engineering; IME - Industrial Management and Engineering; INF - Informatics Engineering).

However, according to Fisher's exact $(\mathrm{F})$ and chi-square $\left(\chi^{2}\right)$ test results, the differences observed between the various courses are not statistically significant $\left(\chi^{2}=9.842\right.$, $\mathrm{p}=0.132, \mathrm{~F}=9.355, \mathrm{p}=0.149)$. Although there are no statistically significant differences between students, in Industrial Management and Engineering there is a tendency to emphasise assimilating style and Informatics Engineering to emphasise converging style.

\section{Discussion}

As mentioned earlier, the use of the Kolb model in this study is justified based on the fact that its use is expanded, and has shown good results for adult populations in a professional and / or higher education environment, characteristics that are verified in the case in study. Some methodological difficulties, also mentioned, can be overcome with the support of the indications given by the method author in the referred publication. This context facilitates comparative analysis with other case studies published in the literature (Table 8).

Table 8. Comparative results analysis

\begin{tabular}{|c|c|c|c|c|}
\hline Study & Diverger & Assimilator & Converger & Accommodator \\
\hline$[54]$ & $8 \%$ & $39 \%$ & $40 \%$ & $13 \%$ \\
\hline$[50]$ & $11 \%$ & $32 \%$ & $33 \%$ & $24 \%$ \\
\hline$[10]$ & $24 \%$ & $47 \%$ & $24 \%$ & $5 \%$ \\
\hline$[55]$ & $10 \%$ & $40 \%$ & $30 \%$ & $20 \%$ \\
\hline Average & $\mathbf{1 3 . 3 \%}$ & $\mathbf{3 9 . 5 \%}$ & $\mathbf{3 1 . 8 \%}$ & $\mathbf{1 5 . 5 \%}$ \\
\hline Our study (all courses) & $16.7 \%$ & $36.4 \%$ & $31.1 \%$ & $15.9 \%$ \\
\hline IME & $7.4 \%$ & $52.0 \%$ & $26.0 \%$ & $15.0 \%$ \\
\hline INF & $19.0 \%$ & $35.0 \%$ & $37.0 \%$ & $9.0 \%$ \\
\hline CIV & $19.0 \%$ & $29.0 \%$ & $26.0 \%$ & $26.0 \%$ \\
\hline
\end{tabular}


Table 8 analysis provides some findings:

i. The results obtained on the study sample are compatible with others available in the literature, originating from different times and geographies.

ii. Most engineering students are of the assimilator or converger type, which is in accordance with earlier studies [56].

iii. Industrial Management and Engineering students are essentially assimilator-type, clearly distinguishing themselves from the profile of other engineering courses. This result is in line with those obtained by other authors, although using a different methodology [11].

iv. The results obtained on the study sample indicate that there are differences between the styles of students who attend different engineering specialties. This result is in line with those reported in several studies [57] [58].

v. As can be perceived by comparing the diagrams in Figure 2, the overall profile of engineering students belonging to the studied sample is determined mainly by the profiles of students in Industrial Management and Engineering (assimilator) and Informatics Engineering (assimilator and divergent), in which Civil Engineering students do not have a dominant profile. These facts seem to allow us to confirm that, at least for some of the specialties, the learning profile can be used as a vocational predictor [44] [45], although this statement can be considered controversial [24].

vi. There is an identity between the results expressed in Figure 3 and the reading obtained on Table 8, through the characteristics indicated in Table 2.

This study shows results in agreement with those obtained by other authors, by showing that (i) there is a clearly majority learning style in students who opted for an engineering course, although this characteristic in the Civil Engineering course is not as evident as in the other courses; (ii) although there are no statistically significant differences, there is a trend in learning style among students who have chosen to attend various specialties in engineering courses, and, again, this trend is not so evident in the Civil Engineering course; and (iii) although there are no statistically significant differences, there is a trend in learning style between engineering students who have chosen to attend an industrial management course and those who have chosen technological engineering courses, and it is in the Industrial course Management and Engineering that this trend presents greater evidence.

\section{$6 \quad$ Limitations and Future Study Scope}

The biggest limitation affecting this study is the relatively small sample size, although the results of the statistical analysis performed can be considered valid and of the same magnitude order as the samples used in the studies referred to.

Although several authors consider specific factors that condition the learning style [59] [60] [61] [62], these were not considered here. In a future study, factors such as the teacher teaching style, the impact of changing the institutional culture (students in the sample have just began higher education), the nature of the classification and the knowledge on entering higher education, the size of the surveyed sample and the 
sociodemographic characteristics of the respondents such as gender or origin (urban or rural) should be included in a continuity study from the one carried out now, in order to consistently validate and expand the present conclusions.

\section{Conclusion}

This study results are of interest to both teachers and students, as well as to higher education curriculum managers. In particular, concerning teachers, the knowledge of learning styles allows them to adapt the pedagogical practice in the classroom to the varied profiles of students, minimizing the discomfort felt by students immersed in a pedagogical practice that does not stimulate effectiveness and motivation in the teaching-learning process.

Regarding the case study, engineering students, the pedagogical practices should be mostly adapted to the assimilating and convergent learning styles, in principle the majority learning styles in the class, and group work should be used as much as possible. These groups should include and, if possible, be led by students from those two groups of learning styles, who may act as facilitators and inducers for the learning of other styles students who are less comfortable with the pedagogical practice in progress in class. In fact, the student's knowledge of his or her own learning style may allow the adoption of corrective practices for lesser effectiveness in the learning process. Students can use this knowledge to define study strategies and improve group work, using their strengths to their advantage and improving communication between group members [54].

Another issue to be taken into account is the impact of the teacher's learning style which is necessarily reflected in the teaching style - in the pedagogical practice in the classroom, and situations of inadequacy between styles should be avoided. It is certain that it will not be possible to achieve full integration between the teaching style and the learning styles of all students in each class, adequate reflection on what methods to be adopted in terms of pedagogical practice in the classroom should lead to better results and greater satisfaction with the effectiveness of the teaching-learning process.

\section{$8 \quad$ References}

[1] Accreditation Association to Advance Collegiate Schools of Business, "Eligibility Procedures and Accreditation Standards for Business," 2019.

[2] Accreditation Board for Engineering and Technology, "Criteria for Accrediting Engineering Programs," 2019.

[3] I. Markes, "A review of literature on employability skills needs in engineering," European Journal of Emgineering Education, vol.31, 2006, issue 6, vol. 31, nº 6, pp. 637-650, 2011.

[4] S. Kumar e A. Bhandarker, "Experiential Learning and Its Relevance in Business School Curriculum," Developments in Business Simulation and Experiential Learning, vol. 44, pp. 244-251, 2017.

[5] C. Chan e E. Fong, "Disciplinary differences and implications for the development of generic skills: a study of engineering and business students' perceptions of generic skills," 
European Journal of Engineering Education, vol. 43, n 6, pp. 927-949, 2018. https:// doi.org/10.1080/03043797.2018.1462766

[6] J. Holvikivi, "Learning styles in engineering education: the quest to improve didactic practices,” European Journal of Engineering Education, vol. 32, nº 4, pp. 401-408, 2007. https://doi.org/10.1080/03043790701332909

[7] S. Kersten, "Approaches of Engineering Pedagogy to Improve the Quality of Teaching in Engineering Education," em Vocational Teacher Education in Central Asia, Technical and Vocational Education and Training: Issues, Concerns and Prospects, Springer Link, 2018, pp. 129-139. https://doi.org/10.1007/978-3-319-73093-6_14

[8] M. Balfaqeeh, “Understanding Engineering Students' Learning Styles," International Journal of Linguistics and Communication, vol. 5, n 1, pp. 44-55, 2017.

[9] R. Felder e R. Brent, "Understanding Student Differences," Journal of Engineering Education, vol. 94, no 1, pp. 57-72, 2005.

[10] N. Cagiltay, "Using learning styles theory in engineering education," European Journal of Engineering Education, vol. 33, n 4, p. 415-424, 2008. https://doi.org/10.1080/0304 $\underline{3790802253541}$

[11] J. Bajpai, A. SinghRaghuwanshi e A. Taskar, "Learning Style: Engineering Students vs Management Students," International Journal of Advanced Research, vol. 6, n 1, pp. 893897, 2018. https://doi.org/10.21474/ijar01/6298

[12] B. Ictenbas e H. Eryilmaz, "Determining Learning Styles of Engineering Students to Improve the Design of a Service Course," Procedia - Social and Behavioral Sciences, vol. 28, pp. 342-346, 2011. https://doi.org/10.1016/j.sbspro.2011.11.065

[13] R. M. Felder, "Matters of style," ASEE Prism, vol. 6, n 4, p. 18-32, 1996.

[14] P. Rosati, R. K. Dean e S. M. Rodman, "A study of the relationship between students' learning styles and instructors' lecture styles," IEEE Transactions on Education (Volume: 31, Issue: 3, Aug. 1988), vol. 31, n 3, pp. 208-212, 1988. https://doi.org/10.1109/13.2313

[15] R. P. Bostrom, L. Olfman e M. K. Sein, "The Importance of Learning Style in End-User Training," MIS Quarterly, vol. 14, n 1, pp. 101-119, 1990. https://doi.org/10.2307/249313

[16] H. Pashler, M. M. McDaniel, D. Rohrer e R. Bjork, "Learning styles concepts and evidence," Psychological science in the public interest, vol. 9, n 3, p. 105-119, 2008. https:// doi.org/10.1111/j.1539-6053.2009.01038.x

[17] E. Bernardes e M. Hanna, "How do management Students Prefer to Learn? Why should we Care?" International Journal for the scholarship of Teaching and Learning, vol. 3, n 1, pp. 1-13, 2009. https://doi.org/10.20429/ijsotl.2009.030121

[18] A. Grasha, "Using Traditional Versus Naturalistic Approaches to Assessing Learning Styles in College Teaching," Journal on Excellence in College Teaching, vol. 1, pp. 23-38, 1990. https://doi.org/10.1080/87567555.1990.10532207

[19] A. M. Zapalska e H. Dabb, "Learning Styles," Journal of Teaching in International Business, vol. 13, n 3-4, pp. 77-97, 2002. https://doi.org/10.4324/9781315864846-6

[20] J. W. Keefe, "Learning style: An overview," em Student learning styles: Diagnosing and prescribing programs, Reston, VA, National Association of Secondary School Principals, 1979, pp. 1-17.

[21] J. Reid, "The Learning Style Preferences of ESL Students," Tesol Quarterly, vol. 21, n 1, pp. 87-111, 1987. https://doi.org/10.2307/3586356

[22] R. Felder e L. Silverman, "Learning and Teaching Styles in Engineering Education," Engineering Education, vol. 78, n 7, pp. 674-681, 1988.

[23] A. Pritchard, Ways of learning: Learning theories and learning styles in the classroom, D. Fulton, Ed., London: Routledge, 2009. 
[24] D. Kolb, Experiential learning: experience as the source of learning and development, Englewood Cliffs, New Jersey: Prentice Hall, 1984.

[25] H. Moayyeri, "The Impact of Undergraduate Students' Learning Preferences (VARK Model) on Their Language Achievement," Journal of Language Teaching and Research, vol. 6, no 1, pp. 132-139, 2015. https://doi.org/10.17507/jltr.0601.16

[26] F. Coffield, D. Moseley, E. Hall e K. Ecclestone, should we be using learning styles? London: Learning and Skills Research Centre, 2004.

[27] D. Mitchell, "Learning style: a critical analysis of the concept and its assessment," em Design for learning: aspects of educational technology, London, Kogan Page, 1994.

[28] L. Curry, "An organization of learning styles theory and constructs," em Annual Meeting of the American Educational Research Association 67th, April, Montreal, Quebec, 1983.

[29] L. McKenna, B. Copnell, A. Butler e R. Lau, "Learning style preferences of Australian accelerated postgraduate preregistration nursing students: A cross-sectional survey," Nurse Education in Practice, vol. 28, pp. 280-284, 2018. https://doi.org/10.1016/j.nepr.2017.10. $\underline{011}$

[30] D. Kolb, The Kolb Learning Style Inventory, Version 3, Boston: Hay Group, 1999.

[31] D. Kolb, Facilitator's guide to learning, Boston: Hay/McBer, 2000.

[32] C. Kayes, "Internal Validity and Reliability of Kolb's Learning Style Inventory Version 3 (1999)," Journal of Business and Psychology, vol. 20, n 2, p. 249-257, 2005. https://doi. org/10.1007/s10869-005-8262-4

[33] K. Nagata, Y. Kigawa e T. Aoki, "Trial for E-Learning System on Information Security Incorporate with Learning Style and Consciousness Factors," International Journal of Engineering Pedagogy, vol. 8, n 3, pp. 120-136, 2018. https://doi.org/10.3991 iijep.v8i3.8163

[34] M. Healey e A. Jenkins, "Learning cycles and learning styles: Kolb's experiential learning theory and its application in geography in higher education," Journal of Geography, vol. 99, pp. 185-195, 2000. https://doi.org/10.1080/00221340008978967

[35] D. Holman, K. Pavlica e R. Thorpe, "Rethinking Kolb's theory of experiential learning in management education: The contribution of social constructionism and activity theory," Management Learning, vol. 8, n 2, pp. 135-148, 1997. https://doi.org/10.1177/135050 $\underline{7697282003}$

[36] W. Chan, "Analyzing Ipsative Data in Psychological Research,” Behaviormetrika, vol. 30, $\mathrm{n}^{\circ}$ I, pp. 99-121, 2003. https://doi.org/10.2333/bhmk.30.99

[37] H. Baron, "Strengths and limitations of ipsative measurement," Journal of Occupational and Organizational Psychology, vol. 69, pp. 49-56, 1996. https://doi.org/10.1111/j.2044$\underline{\text { 8325.1996.tb00599.x }}$

[38] D. Jackson e D. Alwin, “The Factor Analysis of Ipsative Measures," Sociological Methods \& Research, vol. 9, n 2, pp. 218-238, 1980. https://doi.org/10.1177/004912418000900206

[39] E. J. McLean e B. S. Chissom, "Multivariate Analysis of Ipsative Data: Problems and Solutions," em Annual Meeting of the Mid-South Educational Research Association, Memphis, TN, 1986.

[40] M. Batista-Foguet, B. Ferrer-Rosel, R. Serlavós, G. Coender e R. Boyatzis, "An Alternative Approach to Analyze Ipsative Data.Revisiting Experiential Learning Theory.," Frontiers in Psychology, vol. 6, p. Article1742, 2015. https://doi.org/10.3389/fpsyg.2015.01742

[41] D. A. Kolb, Experiential learning: Experience as the Source of Learning and Development, Upper Saddle River, New Jersey: Pearson Education, Inc, 2015.

[42] S. McLeod, "Kolb's Learning Styles and Experiential Learning Cycle," 2017.

[43] D. Kolb e R. Fry, "Toward an applied theory of experiential learning," em Theories of Group Process, C. Cooper, Ed., N. Y., John Wiley \& Sons, 1975, pp. 33-57. 
[44] R. Felder, G. Felder e E. Dietz, "The effects of personality type on engineering student performance and attitudes," Journal of Engineering Education, vol. 91, n 1, pp. 3-17, 2002. https://doi.org/10.1002/j.2168-9830.2002.tb00667.x

[45] C. Jones, C. Reichard e K. Mokhtari, "Are students' learning styles discipline specific?" Community College Journal of Research and Practice, vol. 27, pp. 363-375, 2003. https://doi.org/10.1080/713838162

[46] A. Kolb e D. Kolb, "Kolb's Learning Styles," em Encyclopedia of the Sciences of Learning, N. Seel, Ed., Springer US, 2012, pp. 1698-1703. https://doi.org/10.1007/978-1-4419-1428$\underline{6} 2228$

[47] C. Riener e D. Willingham, "The Myth of Learning Styles," Change: The Magazine of Higher Learning, vol. 42, $\mathrm{n}^{\circ}$ 5, pp. 32-35, 2010. https://doi.org/10.1080/00091383.2010. $\underline{503139}$

[48] A. M. Alzain, S. Clark, A. Jwaid e G. Ireson, "Adaptive Education based on Learning Styles: Are Learning Style Instruments Precise Enough?” International Journal of Emerging Technologies in Learning, vol. 13, n 9, pp. 41-52, 2018. https://doi.org/10.3991 lijet.v13i09.8554

[49] G. Tsoulouhas, D. Georgiou e A. Karakos, "Adaptive Content Presentation in Asynchronous Learning Environments," International Journal of Emerging Technologies in Learning, vol. 7, no 2, pp. 43-49, 2012. https://doi.org/10.3991/ijet.v7i2.1911

[50] A. Kolb e D. Kolb, "The Kolb Learning Style Inventory-Version 3.1 Technical Specifications," HayGroup, 2005.

[51] R. Loo, "Confirmatory factor analyses of Kolb's Learning Style Inventory (LSI-1985), British Journal of Educational Psychology, vol. 69, pp. 213-219, 1999. https://doi.org/10.1348/000709999157680

[52] J. M. Cornwell, P. A. Manfredo e W. P. Dunlap, "Factor Analysis of the 1985 Revision of Kolb's Learning Style Inventory," Educational and Psychological Measurement, vol. 5, $\mathrm{n}^{\circ}$ 2, pp. 455-462, 1991. https://doi.org/10.1177/0013164491512020

[53] L. Willcoxson e M. Prosser, "Kolb's Learning Style Inventory (1985): review and further study of validity and reliability," British Journal of Educational Psychology, vol. 66, pp. 247-257, 1996. https://doi.org/10.1111/j.2044-8279.1996.tb01193.x

[54] J. E. Sharp, "Teaching teamwork communication with Kolb learning style theory," em 31st ASEE/IEEE frontiers in education conference, Reno, NY, 2001. https://doi.org/10.1109/ fie.2001.963699

[55] S.-C. Lin, Y.-Y. Lin, J.-Y. Lin e C.-J. Cheng, "A Study of Kolb Learning Style on Experiential Learning," em Proceedings of 2010 Third International Conference on Education Technology and Training, CNKI, Hubei, China, 2010.

[56] R. E. Terry e J. N. Harb, "Using learning style theory to improve learning and teaching in the engineering classroom," em Proceedings of IEEE Frontiers in Education Conference FIE '93, Washington, DC, USA, 1993. https://doi.org/10.1109/fie.1993.405578

[57] G. M. Johnson e J. A. Johnson, "Learning Style and Preference for Online Learning Support: Individual Quizzes versus Study Groups,” ED-MEDIA 2006 Proceeding, pp. 1861-1868, 2006.

[58] J. D. Vermunt, "Metacognitive, cognitive and affective aspects of learning styles and strategies: A phenomenographic analysis," Higher Education, vol. 31, pp. 25-50, 1996. https://doi.org/10.1007/bf00129106

[59] P. K. Tulsi, M. P. Poonia e P. Anu, "Learning Styles of Engineering Students," Journal of Engineering Education Transformations, vol. 30, n 2, pp. 44-49, 2016. https://doi.org/ $\underline{10.16920 / j e e t / 2016 / \mathrm{v} 30 \mathrm{i} 2 / 105438}$ 
[60] A. R. Jamali e M. M. Mohamad, "Identifying Learning Styles among Engineering Students," Social Sciences \& Humanities, vol. 25, n S, pp. 251 - 258, 2017.

[61] C. Ipbuker, "Learning Styles and Teaching Models in Engineering Education," em Proceedings of the 6th WSEAS International Conference on Engineering Education, Wisconsin, United States, 2008.

[62] L. Alkooheji e A. Al-Hattami, "Learning Style Preferences among College Students," International Education Studies, vol. 11, n 10, pp. 50-63, 2018. https://doi.org/10.5539/ies. $\underline{\mathrm{v} 11 \mathrm{n} 10 \mathrm{p} 50}$

\section{Authors}

Marina Sousa is a professor at the Department of Organization and Management and a researcher at the Interdisciplinary Studies Research Center at the School of Engineering of Polytechnic of Porto, Portugal. She has a specialization in Strategic Management of Universities at the Polytechnic University of Catalunya, a Master degree in Social and Legal Sciences, specialization in Economics, Business and Labour and a $\mathrm{PhD}$ in Economic and Business Sciences from the University of Extremadura. She was Vice-President and member of the Board of Management of the Polytechnic of Porto. She was Chief Executive Officer of the Polytechnic of Porto Foundation. The main fields of interest are: Globalization, Internationalization, European Integration, Strategic Management, Governance of Higher Education and Engineering Education.

Eunice Fontão is a professor at the Department of Civil Engineering and a researcher at the Interdisciplinary Studies Research Center at the School of Engineering of Polytechnic of Porto, Portugal. She graduated in Civil Engineering from Faculty of Engineering of the University of Porto and completed a Master in Environmental Engineering and a $\mathrm{PhD}$ in Civil Engineering in the same University. She began her career in construction business. She was member of the School of Engineering of Polytechnic Representatives Council is at the present a member of the Technical and Scientific Council. The main fields of interest are: Energy Efficiency Urban Planning and Engineering Education. Email: emf@isep.ipp.pt

Article submitted 2020-04-27. Resubmitted 2020-06-08. Final acceptance 2020-06-14. Final version published as submitted by the authors. 